\title{
Stratigraphy and tectonic significance of the Lower to Middle Devonian McAdams Lake Formation, Cape Breton Island, Nova Scotia
}

\author{
C.E. White ${ }^{1}$ and S.M. Barr ${ }^{2}$ \\ 'Department of Natural Resources, P.O. Box 698, Halifax, Nova Scotia B3J 2T9, Canada \\ ${ }^{2}$ Department of Geology, Acadia University, Wolfville, Nova Scotia BOP 1X0, Canada
}

Received May 14, 1998

Accepted September 29, 1998

The McAdams Lake Formation consists of a lower member composed of green-grey to black sandstone, siltstone, shale, and minor conglomerate, and an upper member composed predominantly of grey conglomerate and sandstone, with minor black shale. A lens of red shale, siltstone, and sandstone with minor conglomerate is also present in the upper member. The total thickness of the formation is approximately $1 \mathrm{~km}$. Fossil plant fragments and palynology indicate an age of latest Emsian to Early Eifelian (latest Early to Middle Devonian). The presence of a small, fine-grained quartz syenite intrusion probably led to the previously reported occurrence of volcanic rocks in the formation.

Characteristics of the lower member suggest deposition in a shallow lacustrine shoreline setting with intermittent, rapid deposition of coarse sediments in a fan delta near a faulted margin. The upper member is interpreted to represent an increase in topographic relief and a progradation of the fan delta to fill the basin, with braided channels present near the fan delta toe. The presence of carbonaceaous shale in this member indicates intermittent swampy conditions or transgression of lacustrine conditions over the fan delta.

The McAdams Lake Formation was deposited on the Mira terrane in a half-graben formed by extension along the boundary between the Mira and Bras d'Or terranes, at the initial stage of development of the Sydney Basin. A hiatus of ca. $40 \mathrm{Ma}$ occurred between deposition of the McAdams Lake Formation and the unconformably overlying Grantmire Formation. During this time the McAdams Lake Formation underwent a period of compressive deformation that resulted in northeast-trending minor folds on an antiformal structure. The McAdams Lake Formation and equivalent units in Atlantic Canada may represent an earlier Horton-like basin system with similar facies and economic possibilities that have been previously unexplored.

La Formation de McAdams Lake est constituée d'un membre inférieur formé de grès allant du gris verdâtre au noir, de siltstone, de schiste et d'une petite quantité de conglomérat, ainsi que d'un membre supérieur principalement composé de grès et de conglomérat gris, avec une petite quantité de schiste noir. Une lentille de schiste rouge, de siltstone et de grès accompagnés d'une faible quantité de conglomérat est également présente dans le membre supérieur. La Formation a une épaisseur totale d'environ un kilomètre. Les fragments de plantes fossiles et les données palynologiques la situent à la période du début de l'Emsien supérieur à l'Eifélien inférieur (début du Dévonien inférieur au Dévonien moyen). La présence d'une petite intrusion de syénite quartzique à grain fin a probablement mené à l'occurrence de roches volcaniques signalée antérieurement dans la Formation.

Les caractéristiques du membre inférieur permettent de supposer une sédimentation orientée le long d'une rive lacustre peu profonde avec accumulation rapide et intermittente de sédiments grossiers dans un delta alluvial s'étant formé près d'un bord faillé. On interprète le membre supérieur comme une représentation d'un accroissement du relief topographique et une progradation du delta alluvial cherchant à remplir le bassin, avec la présence de canaux anastamosés près du front du delta alluvial. La présence de schiste charbonneux dans ce membre révèle des conditions marécageuses intermittentes ou une transgression des conditions lacustres au-dessus du delta alluvial.

La Formation de McAdams Lake s'est déposée sur le terrane Mira dans un demi-graben formé par prolongement le long de la limite séparant les terranes Mira et Bras d'Or, au début du développement du bassin de Sydney. Un hiatus sédimentaire d'environ $40 \mathrm{Ma}$ est survenu entre le dépôt de la Formation de McAdams Lake et celui de la Formation sus-jacente discordante de Grantmire. La Formation de McAdams Lake a alors subi une période de déformation causée par une compression qui a produit des plis orientés vers le nord-est sur une structure antiforme. La Formation de McAdams Lake et les unités équivalentes des provinces de l'Atlantique pourraient représenter un système de bassin de type Horton offrant des faciès semblables et des possibilités économiques auparavant inexplorées.

[Traduit par la rédaction]

INTRODUCTION

The McAdams Lake Formation in central Cape Breton Island (Fig. 1) is one of the earliest records of sediment deposition in the Devonian-Carboniferous Sydney Basin, part of the larger Maritimes Basin (Fig. 1, inset). The formation covers a wedge-shaped area of approximately $18 \mathrm{~km}^{2}$, between the Coxheath Hills to the southeast and the Boisdale 


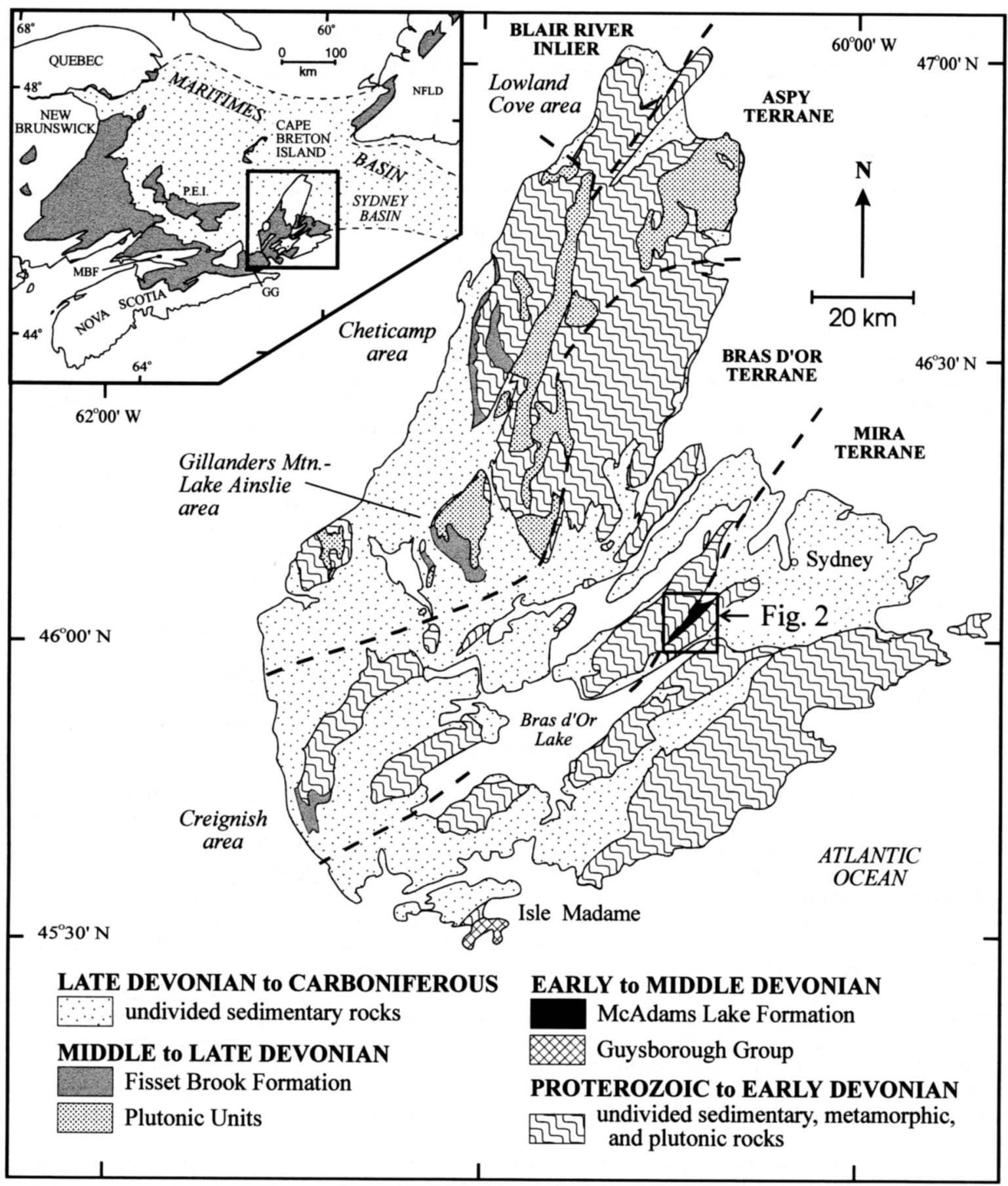

Fig. 1. Simplified geological map and tectonostratigraphic terranes of Cape Breton Island (after Barr and Raeside, 1989), showing the location of the McAdams Lake Formation. Inset map shows the Maritimes Basin, Sydney Basin, and other areas referred to in the text. $G G=$ Guysborough Group; MBF = Murphy Brook Formation.

Hills to the northwest (Fig. 2). Bell and Goranson (1938) defined and named the formation, and described it as fresh water arkose and conglomerate interbedded with what they interpreted to be fragmental volcanic rocks. An Early to Middle Devonian age was assigned, based on plant fossils (Bell, 1938; Bell and Goranson, 1938; Dorf and Copper, 1943). It should be noted that the original name assigned by Bell and Goranson (1938) was McAdam Lake Formation. However, Williams et al. (1985) referred to the formation as McAdams Lake Formation, and McAdams Lake is the name used on NTS Sheet $11 \mathrm{~K} / 1$ and by local residents for the lake after which the unit was named by Bell and Goranson (1938). Hence, the name McAdams Lake Formation is used here.

The purpose of this paper is to report the results of recent mapping of the McAdams Lake Formation, which has led to the establishment of an internal stratigraphy as well as an interpretation of the structural history and of the significance of the formation in regional tectonic models. Igneous components of the formation, previously interpreted to be volcanic, are shown to be intrusive, and hence not necessarily of Devonian age. 

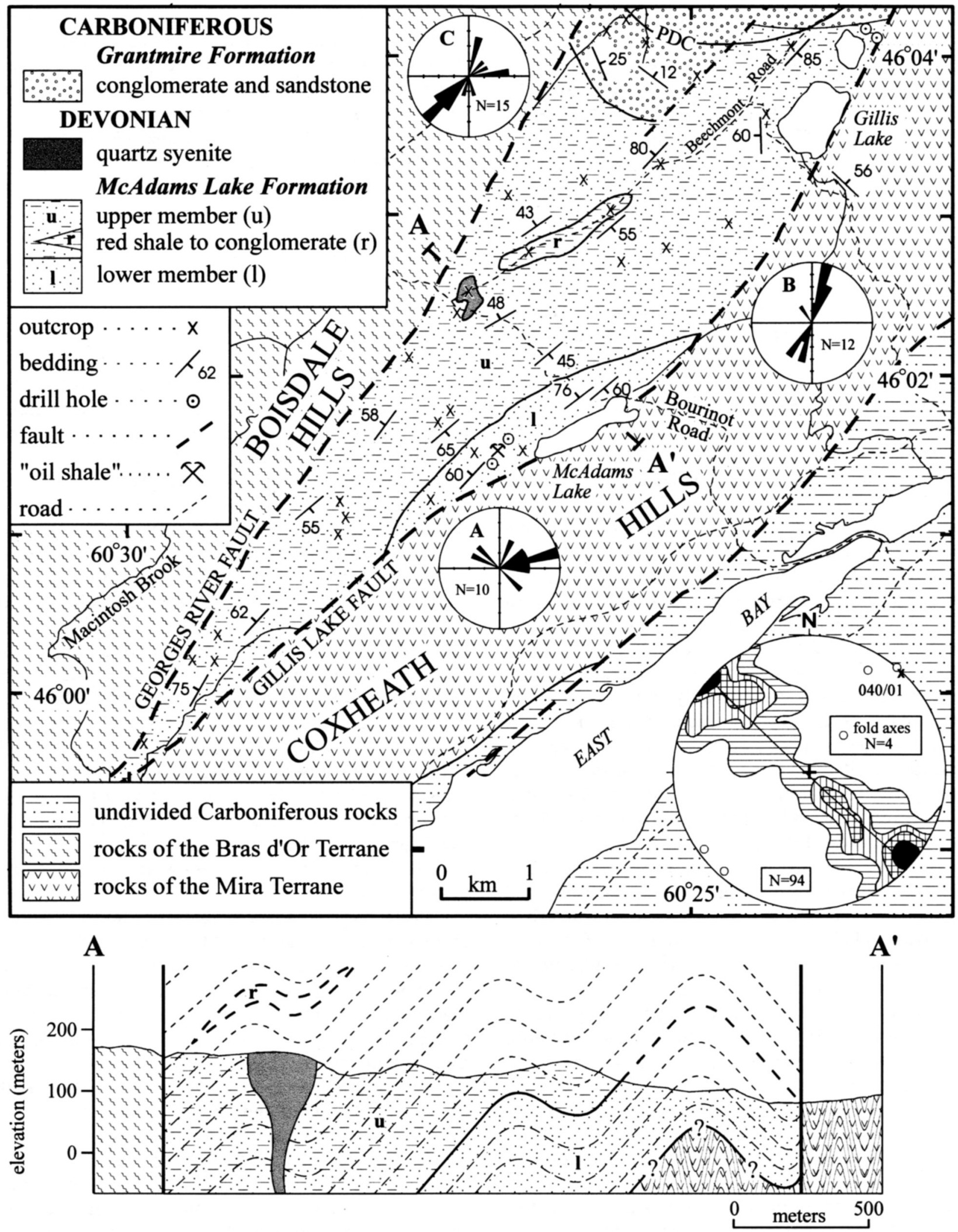

Fig. 2. Geological map and cross-section A-A' of the McAdams Lake area, simplified from White and Barr (1998a). PDC = previously designated contact between the McAdams Lake Formation and Grantmire Formation, from Bell and Goranson (1938). Paleocurrent data shown in $5 \%$ increments with rose diagram $A=$ lower member, $B=$ near base of upper member, $C=$ near top of upper member. Contoured poles to bedding data plotted on stereonet with contour intervals at $3,6,9$, and $>9 \%$ per unit area. $X=$ regional fold axis. Open circles $=$ minor fold axes. 


\section{Geological setting}

The McAdams Lake Formation is bounded on the northwest and southeast by faults, and is unconformably overlain by the Grantmire Formation on the northeast (Fig. 2). The Georges River Fault (Giles, 1983; Boehner and Giles, 1986) on the northwest separates the McAdams Lake Formation from the Boisdale Hills belt, part of the Bras d'Or terrane of Barr and Raeside (1989). This major fault was first recognized by Bell and Goranson (1938) but was not named. The Boisdale Hills belt consists of marble, gneiss, and quartzite, intruded by ca. $560 \mathrm{Ma}$ granitic to dioritic plutons (Barr and Setter, 1986; Raeside, 1989; Barr et al., 1990) and a ca. $510 \mathrm{Ma}$ syenogranitic pluton (White et al., 1994), as well as a faultbounded band of Cambrian to Ordovician sedimentary and volcanic rocks (Hutchinson, 1952; White et al., 1994). The Gillis Lake Fault on the southeast separates the McAdams Lake Formation from the Coxheath Hills belt, part of the Mira terrane of Barr and Raeside (1989). The Coxheath Hills belt consists of ca. $620 \mathrm{Ma}$ basaltic, andesitic, and rhyolitic flows and tuffs of the Coxheath Hills Group, intruded by comagmatic dioritic to granitic plutons and unconformably overlain by Cambrian to Ordovician sedimentary rocks (Hutchinson, 1952; Barr et al., 1992, 1996). The contact between the McAdams Lake Formation and the Coxheath Hills belt was interpreted to be an unconformity by Bell and Goranson (1938), Weeks (1954), and Poole (1967), based on the presence in the McAdams Lake Formation of granitic and volcanic clasts lithologically similar to units in the Coxheath Hills belt. However, fracturing and local brecciation in outcrops and drill core close to the inferred contact indicate that it is now faulted, although the original relationship may have been unconformable. The fault, here termed the Gillis Lake Fault, merges with the Georges River Fault to the southwest (Fig. 2).

On the northeast, the McAdams Lake Formation is unconformably overlain by red conglomerate, sandstone, and shale of the Grantmire Formation. It should be noted that, although Weeks (1954) described the McAdams Lake Formation in his report, he showed the area of outcrop as Grantmire Formation on his geological maps of the area (Weeks, 1955, 1958), presumably due to an error during map preparation. Bell and Goranson (1938) originally included the Grantmire Formation in the basal part of the Windsor Group. However, based on mapping in the Sydney Basin area and the presence of Middle to Late Tournaisian spores (R. Boehner, personal communication, 1998), Giles (1983) and Boehner and Giles (1986) re-assigned the Grantmire Formation to the Horton Group.

Detailed mapping during the present study resulted in moving the position of the contact between the Grantmire and McAdams Lake formations to the southwest of the previously designated contact (cf. Bell and Goranson, 1938; Boehner and Giles, 1986), offset by an inferred northeast trending fault (Fig. 2). Although the contact is not exposed, major differences in bedding orientations occur between the two formations (Fig. 2), indicating that the contact is an angular unconformity. The previous position of the contact was based largely on a colour change from red to grey, and because no significant change occurred in lithology or bedding orientation, the Grantmire Formation was interpreted to lie disconformably or with only slight unconformity on the McAdams Lake Formation (Bell, 1938; Bell and Goranson, 1938; Helmstaedt and Tella, 1973; Mazerolle and MacGillivary, 1975; Boehner and Giles, 1986). However, evidence from drill core logs (Oldale, 1967) indicates that the lowermost part of the Grantmire Formation locally includes interbedded red and grey strata. Hence, the colour change does not mark the contact between the Grantmire Formation and underlying McAdams Lake Formation, as was previously assumed.

\section{STRATIGRAPHY AND AGE}

Based on the present study, the McAdams Lake Formation is divided into a lower member composed dominantly of green-grey to black sandstone, siltstone, shale, and minor conglomerate, and an upper member composed of grey conglomerate and sandstone. A mappable lens of red siltstone, sandstone, shale, and conglomerate occurs within the dominantly grey upper member (Fig. 2). The thickness of the formation varies from a few tens of metres where it is faulted between rocks of the Boisdale Hills and Coxheath Hills belts in the southwest to approximately $1 \mathrm{~km}$ in the northeast (Fig. 2). The latter thickness is poorly constrained and is determined from a structural cross-section through the best exposure of outcrop in the formation. It does not take into account any possible faults within the formation which may duplicate the section. A previously quoted thickness of $340 \mathrm{~m}$ (e.g., Williams et al., 1985; Gibling et al., 1987; Gibling, 1995) appears to have resulted from a misprint in a paper by Alcock $(1947$, p. 116) who incorrectly inserted the word "Lake" when he was referring to the thickness of the Silurian McAdam (now McAdam Brook; Williams et al., 1985) Formation in the Arisaig area, which has a thickness of $340 \mathrm{~m}$.

Based on palynological analyses (Table 1) from coaly shale and siltstone samples, McGregor $(1966,1977,1995)$ assigned a latest Emsian to Early Eifelian age to the McAdams Lake Formation, with Early Eifelian (earliest Middle Devonian) preferred. This age is consistent with the earlier interpretations of Early to Middle Devonian age based on plant fragments of Arthrostigma Psilophyton, Arthrostigma gracile Dawson, and a species of Estheria (Bell, 1938; Bell and Goranson, 1938; Dorf and Copper, 1943).

The McAdams Lake Formation was examined at approximately 50 outcrops during the present study (White and Barr, 1998a). These locations expose only limited portions of the entire formation and no complete sections exist. Thirty-seven paleocurrent measurements were made at these outcrops, and twenty-five samples were collected for petrographic studies. Unpublished core logs from four drill holes totalling $356 \mathrm{~m}$ in length from two areas (Fig. 2) were also examined. The two holes near Gillis Lake were drilled by Mariner Mines Limited in 1965 (Oldale, 1967) whereas the two holes near McAdams Lake were drilled by the Nova Scotia Department of Mines in 1976 (MacDougall and Grimm, 
Table 1. List of spores recovered from the McAdams Lake Formation.

Species *

Reference

$\begin{array}{ll}\text { Acinosporites lindlarensis Riegel 1968 var. lindlarensis } & 2,3 \\ \text { Ancyrospora spp. (2 species) } & 1,2,3 \\ \text { ?Ancyrospora eurypterota } \text { Riegel } & 2 \\ \text { Ancyrospora nettersheimensis Riegel 1973? } & 2,3 \\ \text { Apiculatasporites sp. } & 1 \\ \text { ?Apiculatasporites microconus (Richardson) McGregor and Camfield 1982 } & 2,3 \\ \text { Apiculiretusispora brandtii Streel 1964 } & 3 \\ \text { Apiculiretusispora plicata (Allen) Streel 1967 } & 3 \\ \text { Archaeotriletes incompositus Chibrikova } & 1 \\ \text { ?Corystisporites multispinosus Richardson 1965 var. multispinosus } & 3 \\ \text { ?Dibolisporites crassus (Kedo) McGregor and Camfield 1982 } & 3 \\ \text { Dibolisporites echinaceus (Eisenack) Richardson 1965 } & 3 \\ \text { Dibolisporites echinaceus (Eisenack) Richardson 1965 var. echinaceus } & 2 \\ \text { Dibolisporites echinaceus (Eisenack) Richardson 1965 var. gibberosus } & 2 \\ \text { Dibolisporites eifeliensis (Lanninger) McGregor } & 2 \\ \text { Dibolisporites quebecensis McGregor } & 2 \\ \text { Emphanisporites annulatus McGregor 1961 } & 2,3 \\ \text { Emphanisporites rotatus McGregor 1961 } & 2,3 \\ \text { ?Grandispora sp. } & 2,3 \\ \text { ?Hymenozonotriletes kedoae Riegel } & 2 \\ \text { Hystricosporites sp. } & 1 \\ \text { ?Perotrilites eximius Allen } & 2 \\ \text { Phyllothecotriletes triangulatus Streel } & 1 \\ \text { ?Retusotriletes devonicus Naumova cf. var. echinatus Chibrikova } & 1 \\ \text { Retusotriletes spp. } & 1,2 \\ \text { Samarisporites sp. } & 1 \\ \text { Stenozontriletes sp. } & 1 \\ \text { Verruciretusispora multituberculata (Lanninger) McGregor } & 2\end{array}$

1. McGregor, D.C. 1966.

2. McGregor, D.C. 1977.

3. McGregor, D.C. 1995.

Note: The reader should refer to the Geological Survey of Canada Atlantic, Marine Resources Geoscience Subdivision for possible revisions.

1977). The latter two holes intersected bedding at low angles and thus provide limited stratigraphic information.

\section{Lower member}

The lower member crops out adjacent to the Coxheath Hills belt in the vicinity of McAdams Lake, and is best exposed in road cuts along the Bourinot Road (Fig. 2). It also occurs in drill core from west of McAdams Lake (Smith and Naylor, 1990, and unpublished core logs). It has a thickness of approximately $300 \mathrm{~m}$ but thins to the northeast and southwest. It consists of green-grey sandstone and siltstone, dark grey to black shale, and minor grey conglomerate. These lithologies are interbedded on a scale of 5 to $100 \mathrm{~cm}$ and commonly arranged in fining-upward sequences 0.5 to $5 \mathrm{~m}$ thick (Fig. 3a). The base of most sequences consists of grey, mi- caceous, fine- to very coarse-grained sandstone to pebble conglomerate with sharp flat or deeply scoured bases (Fig. 3b). The conglomerates are sand matrix-supported and moderately stratified and sorted, and generally display a finingupward trend to sandstone. Clast lithologies are diverse but generally include abundant rounded pebbles of quartzite with subordinate granite, diorite, basalt, rhyolite, slate, and marble. These clast lithologies are typical of units in the adjacent Bras d'Or and Mira terranes. The matrix is classified as lithic subarkose to sublitharenite (Ehlers and Blatt, 1982). The overlying sandstones locally contain lags of pebbles, fossil plant fragments, and more rarely siltstone rip-up clasts. Internal sedimentary structures are not common and are restricted to horizontal layering near the base. The sandstones are poorly sorted and contain angular to subangular quartz, feldspar, biotite, muscovite, chlorite, and opaque minerals. 

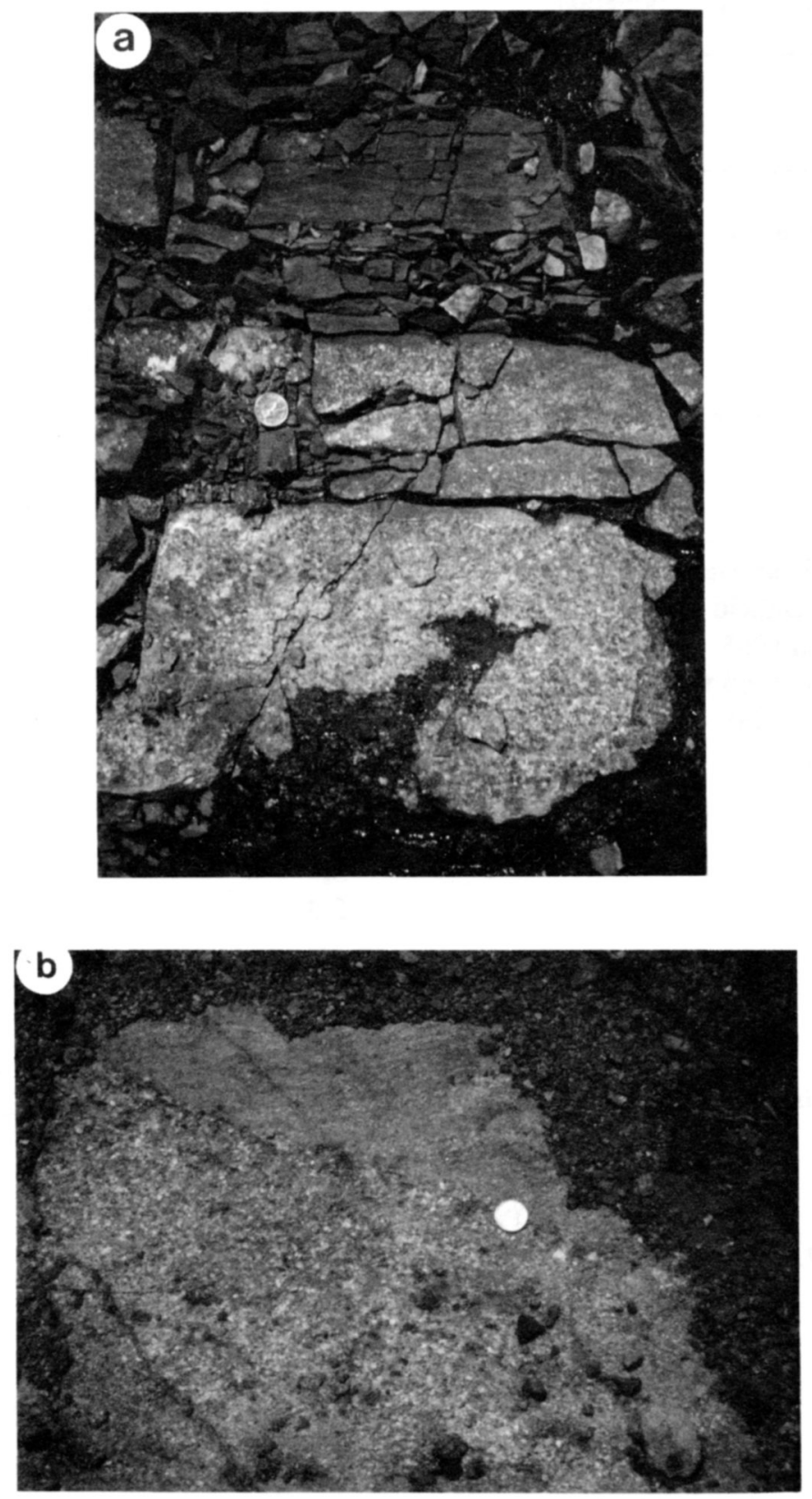

Fig. 3. (a) Photograph showing a typical fining-upward sequence in the lower member of the McAdams Lake Formation. The coin is $2.5 \mathrm{~cm}$ in diameter. (b) Photograph showing the base of a fining-upward sequence (at coin, $2.5 \mathrm{~cm}$ in diameter), with basal pebble conglomerate (above coin) forming a channel in underlying sandstone (below coin).

Rock fragments identifiable in thin section consist dominantly of quartzite and marble with subordinate basalt and slate. The sandstones are classified as lithic subarkose to feldspathic litharenite (Ehlers and Blatt, 1982).

Many of the sandstone units fine upward through a thin $(<1 \mathrm{~cm}$ thick) gradational top to an overlying greenish grey or rarely reddish brown siltstone, typically $1 \mathrm{~cm}$ to $50 \mathrm{~cm}$ in thickness. The siltstone is typically argillaceous and micaceous with a sharp to gradational top. Grain size is uniform but a few examples show grading. Internal stratification is horizontal with minor ripple cross laminations near the top. Tool marks, such as scratches and prods, and rootlet traces are preserved on many of the bedding planes. Desiccation cracks are also locally preserved.

The fining-upward sequence is capped by thin $(5 \mathrm{~cm}$ to $50 \mathrm{~cm}$ thick), dark grey to black shale to silty shale with a sharp base and top. Some of the black shale is rich in organic material and has been described as oil shale (Gilpin, 1899; Potter, 1977) or carbonaceous or coaly shale (Smith and Naylor, 1990). Thin ( $<30 \mathrm{~cm}$ thick) coal seams are also present (Fletcher, 1878; Potter, 1977). Oil shale was reported to outcrop near the west shore of McAdams Lake on a brook, where it was mined (see Economic Potential section), and could be traced to a roadcut farther northeast along the Bourinot Road (Fletcher, 1878; Gilpin, 1899; Potter, 1977; Smith and Naylor, 1990). The more organic-rich layers are typically sheared with polished or slickensided fractures. In drill core, thin $(2$ by $0.5 \mathrm{~cm})$ pyrite lenses locally occur parallel to bedding (unpublished core logs).

Paleocurrent data are sparse (6 measurements collected from pebble imbrication and $\mathbf{4}$ from ripples and tool marks). The pebble imbrication data indicate sediment dispersal to the east-northeast, parallel to the Coxheath Hills basement block, whereas ripple crests indicate northwest and southeast paleocurrents (Fig. 2).

Some conglomeratic layers are not associated with the fining-upward sequences and occur intermittently throughout the sequence as massive, unstratified beds, 1 to $3 \mathrm{~m}$ thick. Although similar in clast lithologies to the "fining-upward" conglomerate, clasts typical of the Bras d'Or terrane (quartzite, granite, marble, and rare gneiss) predominant. These conglomerates are typically pinkish grey, poorly sorted with pebbleto cobble-sized clasts set in an angular, coarse sand- to granulesupported or clast-supported matrix. The sand-supported matrix is similar in composition to that in the "fining-upward" conglomerate and can be classified as lithic subarkose to lithic arkose (Ehlers and Blatt, 1982). No reliable paleocurrent data was retrieved from these conglomeratic layers.

\section{Upper member}

The upper member constitutes most of the McAdams Lake Formation (Fig. 2). It consists of grey conglomerate, sandstone, and minor carbonaceous shale, and appears to conformably overlie the lower member. The upper member is poorly exposed and continuous sections are rare, although large cliffs and ridges parallel to bedding are present in the southwestern part of the unit adjacent to the Boisdale Hills (Fig. 2). The predominant component is grey and less commonly maroon or brown, polymictic, poorly sorted, matrixsupported conglomerate. Minor grey to locally maroon coarse sandstone is interbedded with the conglomerate, and in places sandstone beds predominate over conglomerate. The conglomerate typically forms massive beds ( $>2 \mathrm{~m}$ thick) that are locally stacked into $25 \mathrm{~m}$ thick sequences; however, some conglomeratic layers fine upward into sandstone. The conglomerate contains rounded clasts up to $50 \mathrm{~cm}$ in diameter, although most clasts are 5 to $10 \mathrm{~cm}$ in diameter. The clasts are set in a matrix of poorly sorted, angular, micaceous, locally K-feldspar-rich, coarse sandstone to granule stone. The matrix can be classified as lithic subarkose to felds- 
pathic litharenite (Ehlers and Blatt, 1982). Clast lithologies are similar to those in conglomerate of the underlying member, although hornblende-bearing granite to granodiorite, marble, gneiss, and jasper clasts are locally more abundant and volcanic clasts are generally lacking. Most of these clasts are typical of lithologies in the adjacent Bras d'Or terrane, although the source of the jasper clasts is uncertain. The bases of the conglomerate units may be either flat or deeply scoured. The scoured bases in pebbly conglomerates locally display clast imbrication and broad cross-stratification and may cut down into one another.

Sandstone beds are typically $10 \mathrm{~cm}$ to $2 \mathrm{~m}$ thick, fine upward from sharp flat to scoured bases with fairly sharp tops and, in good exposures, some beds are seen to pinch out laterally. The beds may be massive, horizontally stratified, or cross stratified, with small-scale cross stratification. Plant fragments are not abundant. Pebbles occur in the sandstone as thin lags or as discrete thin strata, or dispersed throughout the bed. The sandstone contains poorly sorted angular quartz, feldspar (microcline and plagioclase), mica, and rock fragments and can be classified as subarkose to lithic subarkose (Ehlers and Blatt, 1982).

In contrast to the lower member, black carbonaceous shale appears to be a minor component of the upper member, although this may be, at least in part, because of poor exposure. Where present, black shale beds are thin $(<1 \mathrm{~m}$ thick), have sharp flat bases and tops, and are interbedded with cobble to boulder conglomerate. Plant fragments are common, although these units are typically sheared with polished and slickensided fractures.

A mappable lens of red shale, siltstone, sandstone, and conglomerate within the upper member crops out along Beechmont Road (Fig. 2). It consists predominantly of red to brown to locally maroon shale and siltstone. These interbeds range from $1 \mathrm{~cm}$ to $50 \mathrm{~cm}$ in thickness, with sharp to gradational bases and tops. The siltstone is typically calcareous and massive to finely laminated. Green-grey reduction spots and streaks and root traces are common. The shale and siltstone is commonly interbedded with red to brown, fine- to coarse-grained sandstone. Beds are $10 \mathrm{~cm}$ to $1 \mathrm{~m}$ thick, may have sharp scoured or gradational flat bases, and internal horizontal lamination. Cross lamination is not common. The sandstone consists of angular quartz and feldspar grains in a matrix of hematite-stained clay and carbonate cement, and is classified as subarkose to quartz arenite (Ehlers and Blatt, 1982).

Red-brown, poorly sorted, matrix-supported pebble conglomerate occurs in minor massive beds $50 \mathrm{~cm}$ to $2 \mathrm{~m}$ thick. The conglomerate has rounded clasts set in a friable matrix of poorly sorted, angular quartz, feldspar, hematitic clay, and minor calcareous cement. Clast lithologies include rounded quartzite, granodiorite, and granite with subordinate marble, jasper and intraformational clasts.

Paleocurrent data for the upper member were collected near the contact with the underlying lower member (10 measurements from pebble imbrication and 2 from trough crossstratification) and close to the top of the member (12 measurements from pebble imbrication and 3 from trough crossstratification). These data indicate a northeast and south- west sediment dispersal pattern parallel to the axis of the formation and the bordering faults.

\section{QuARTZ SYENITE}

Felsic volcanic rocks have been reported in the McAdams Lake Formation (e.g., Bell and Goranson, 1938; Helmstaedt and Tella, 1973; Mazerolle and MacGillivary, 1975; Keppie, 1979; Gibling et al., 1987; Gibling, 1995). No volcanic rocks were found during the present study, but in the area where they were reported to occur, the formation is intruded by fine-grained pink to brown quartz syenite which may have been mistaken for volcanic rocks in the absence of petrographic study.

The quartz syenite occurs in the upper member, and is best exposed along the Boisdale and Beechmont roads (Fig. 2). It is fine-grained to aphanitic with miarolitic cavities, and locally displays a thin chilled margin against adjacent sedimentary rocks. The rock is composed of a network of euhedral K-feldspar laths and minor interstitial quartz and biotite. Small $(<5 \mathrm{~mm})$ widely scattered phenocrysts of amphibole and plagioclase occur in many samples. The amphibole is partially to completely replaced by chlorite. Plagioclase phenocrysts are blocky, display optical evidence of zoning, and are partially sericitized. Locally the amphibole and plagioclase phenocrysts occur as glomeroporphyritic clusters. Accessory phases include apatite and opaque minerals.

Three samples of the quartz syenite, representing various textural varieties, were collected for whole-rock chemical analysis (Table 2). The three analyses are similar, with $\mathrm{SiO}_{2}$ contents ranging from 62 to $64 \%$ (Fig. 4a). Based on normative mineralogy, the samples are classified as alkali feldspar quartz syenite to alkali feldspar granite (Fig. 4b), reflecting their high $\mathrm{K}_{2} \mathrm{O}(4.01-4.35 \%)$ and $\mathrm{Na}_{2} \mathrm{O}(3.86$ $4.20 \%)$ and low $\mathrm{CaO}(0.70-1.02 \%)$ contents. Relatively high loss-on-ignition values $(2.7-3.6 \%)$ are consistent with the degree of alteration apparent in thin section. Low $\mathrm{Nb} / \mathrm{Y}$ ratios indicate that the syenite is subalkalic (Fig. 5a), and low $\mathrm{FOO} / \mathrm{MgO}$ ratios indicate calc-alkalic, rather than tholeiitic, affinity (Fig. 4a). Other chemical characteristics, illustrated by a multi-element variation diagram (Fig. 5b) include high $\mathrm{Ba}, \mathrm{Zn}, \mathrm{Sr}$, and $\mathrm{P}$ and low $\mathrm{Pb}, \mathrm{Rb}, \mathrm{Th}, \mathrm{Nb}$, and $\mathrm{Y}$ compared to the average I-type granite. Other than being younger than its host rocks (Middle Devonian), the age of the quartz syenite is unknown. It could be related to Middle Devonian (and younger?) plutonic rocks which occur at scattered locations in southeastem Cape Breton Island (Barr and Macdonald, 1992). The recognition of the intrusive nature of the quartz syenite indicates that the common assumption that the McAdams Lake Formation includes a volcanic component is incorrect.

\section{STRUCTURAL GeOLOGY}

Based on bedding orientations, sedimentary facing directions, and the distribution of stratigraphic units, the dominant structure in the McAdams Lake Formation appears to be an antiform, with local minor folds (Fig. 2, cross section). However, 
Table 2. Geochemical analyses.

\begin{tabular}{lrrr}
\hline $\begin{array}{l}\text { Sample } \\
\text { Number }\end{array}$ & $\begin{array}{c}\text { ML94- } \\
100\end{array}$ & $\begin{array}{r}\text { ML94- } \\
101 \mathrm{~A}\end{array}$ & $\begin{array}{r}\text { ML94- } \\
101 \mathrm{~B}\end{array}$ \\
\hline & & & \\
$\mathrm{SiO}_{2}$ & 62.70 & 64.35 & 62.03 \\
$\mathrm{TiO}_{2}$ & 0.72 & 0.69 & 0.77 \\
$\mathrm{Al}_{2} \mathrm{O}_{3}$ & 15.52 & 15.22 & 15.80 \\
$\mathrm{Fe}_{2} \mathrm{O}_{3}$ & 4.93 & 5.24 & 5.99 \\
$\mathrm{MnO}$ & 0.09 & 0.07 & 0.08 \\
$\mathrm{MgO}$ & 3.52 & 3.44 & 4.05 \\
$\mathrm{CaO}$ & 0.88 & 0.70 & 1.02 \\
$\mathrm{Na}_{2} \mathrm{O}$ & 3.97 & 3.86 & 4.20 \\
$\mathrm{~K}_{2} \mathrm{O}$ & 4.35 & 4.05 & 4.01 \\
$\mathrm{P}_{2} \mathrm{O}_{5}$ & 0.33 & 0.31 & 0.35 \\
$\mathrm{LOI}$ & 2.80 & 3.60 & 2.70 \\
Total & 99.81 & 101.53 & 101.00
\end{tabular}

Trace elements (ppm)

$\begin{array}{lrrr}\mathrm{Ba} & 1127 & 849 & 1113 \\ \mathrm{Rb} & 55 & 49 & 62 \\ \mathrm{Sr} & 438 & 494 & 592 \\ \mathrm{Y} & 15 & 15 & 16 \\ \mathrm{Zr} & 191 & 187 & 191 \\ \mathrm{Nb} & 6 & 5 & 9 \\ \mathrm{Th} & 10 & 10 & 10 \\ \mathrm{~Pb} & 10 & 10 & 10 \\ \mathrm{Ga} & & & 20 \\ \mathrm{Zn} & 78 & 93 & 110 \\ \mathrm{Cu} & 5 & 20 & 52 \\ \mathrm{Ni} & 48 & 50 & 29 \\ \mathrm{~V} & 104 & 104 & 116 \\ \mathrm{Cr} & 75 & 77 & 112 \\ & & & \end{array}$

ML94-100 = fine grained with

glomeroporphyritic clusters of amphibole and plagioclase.

ML94-101A = aphanitic (chill margin) with sparse phenocrysts of amphibole.

ML94-101B = fine grained with amphibole and plagioclase phenocrysts.

the southeastern limb of the fold is not exposed, and hence the structure could also be a northwest-dipping homocline, although the antiformal model is preferred. The minor folds on the structure trend northeast and are upright and horizontal to subhorizontal (Fig. 2).

This structure contrasts with that in the overlying Grantmire Formation, which is deformed into a regionally broad, northeasttrending, gentle syncline with dips generally less than $30^{\circ}$, although locally adjacent to faults, dips are steeper (Giles, 1983; Boehner and Giles, 1986: Gibling et al., 1987). This structure was noted by early workers (e.g., Bell and Goranson, 1938) and termed the Sydney Harbour Syncline.

The Georges River Fault is a major structure on which $18 \mathrm{~km}$ of dextral strike-slip motion has been postulated, based on offset Carboniferous strata (Giles, 1983; Boehner and
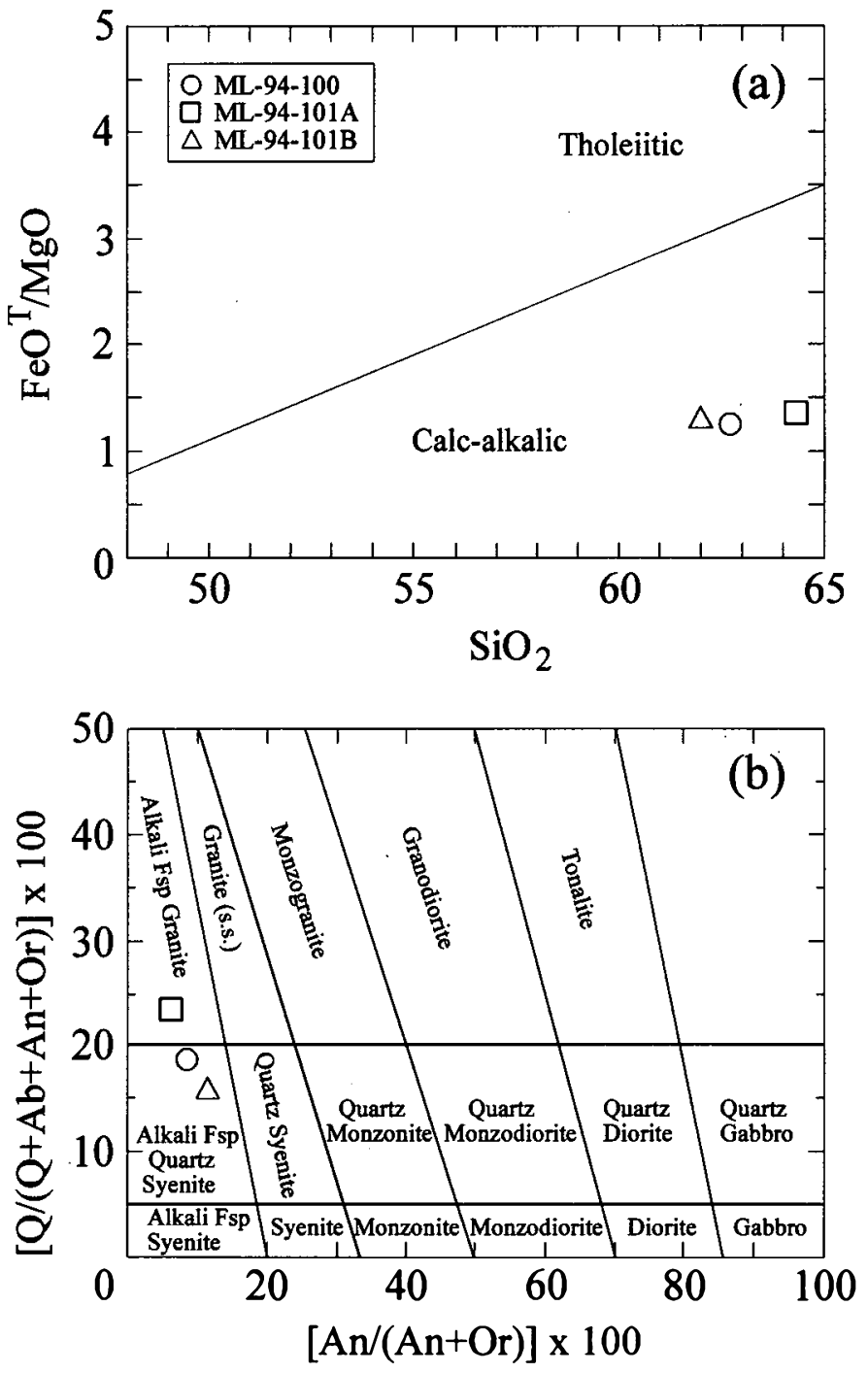

Fig. 4. (a) Geochemical data for 3 samples from the quartz syenite intrusion in the McAdams Lake Formation plotted on the $\mathrm{FeO} / \mathrm{MgO}$ against $\mathrm{SiO}_{2}$ diagram, with tholeiitic/calc-alkalic dividing line from Miyashiro (1974). (b) Normative mineral ratios plotted on the classification diagram of Streckeisen and LeMaitre (1979).

Giles, 1986). In addition, equivalent strata on either side of the fault show considerable differences in thickness, indicating that significant vertical motion was also involved. To the northeast, the fault is overlain by basal strata of the Upper Carboniferous Morien Group (Giles, 1983; Boehner and Giles, 1986: Gibling et al., 1987), indicating that major movement had ceased by Late Carboniferous. The presence of abundant Bras d'Or terrane clasts in the McAdams Lake Formation suggests that it represents the fault-bounded margin along the northwestern side of the McAdams Lake depositional basin during the Early to Middle Devonian.

Evidence for the Gillis Lake Fault was observed in outcrops of the Coxheath Hills belt and in drill core in the Gillis Lake area, but the fault does not appear to cut the Grantmire Formation, which unconformably overlies rocks of the Coxheath Hills belt (Giles, 1983; Boehner and Giles, 1986: Gibling et al., 1987). Hence, movement on the fault was pre-Early Carboniferous. The presence of clasts derived from the Coxheath 

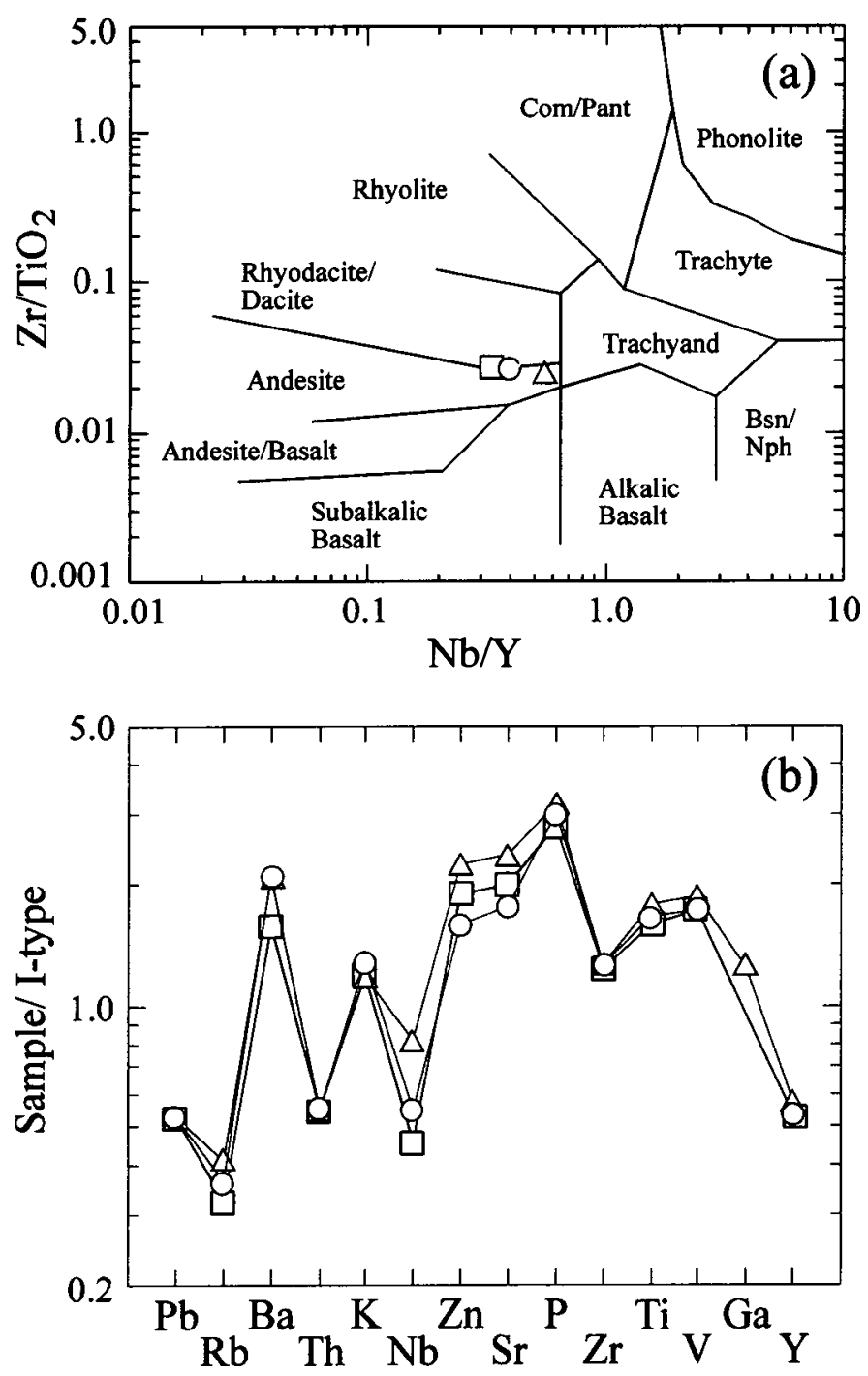

Fig. 5. (a) Quartz syenite samples plotted on the $\mathrm{Zr} / \mathrm{TiO}$, against $\mathrm{Nb} / \mathrm{Y}$ diagram of Winchester and Floyd (1977). (b) Multi-element variation diagram for data from the quartz syenite samples, normalized against the average I-type granite of Whalen et al. (1987).

Hills belt and the Bras d'Or terrane in the lower member of the McAdams Lake Formation suggests that the Georges River and Gillis Lake faults were active in the Early to Middle Devonian. However, clasts from the Coxheath Hills belt are not abundant in the lower member, suggesting that the Coxheath Hills belt was not a significant topographical feature and that the Gillis Lake Fault was not a major structure at that time. It also suggests that the McAdams Lake Formation may have been deposited unconformably on the Coxheath Hills belt, although the contact was later faulted.

\section{Depositional environment}

The lower member of the McAdams Lake Formation consists of repeated fining-upward sequences that suggest the abrupt influx of very coarse sediments into an open body of water, such as a lake, followed by low energy sedimenta- tion. The general upward increase in organic matter and the presence of root casts, coaly shale, and coal at the top of some sequences, together with the local preservation of desiccation cracks, indicate that subaerial exposure may have been periodically achieved. The presence of pyrite in some of the coaly layers suggests that anoxic conditions may have developed. These features suggest low topography, a high water table, and deposition in a lacustrine shoreline setting, probably as fluvial channel fills, near the margin of a broad shallow basin. The massive poorly sorted conglomerate layers throughout the lower member may represent deposits from episodic debris flows in fan deltas near the margins of the basin. The presence of these conglomerates and that fact that they contain mainly Bras d'Or terrane clasts indicates relatively high topographic relief of the Boisdale Hills and rapid erosion, perhaps in response to faulting along the Georges River Fault.

The erosive bases and large clast size in conglomerates of the overlying upper member suggest exceptionally erosive, high-energy conditions, probably due to further increase in the relief of the source area. The conglomerate beds are typically stacked, although in places they are separated by sandstone beds and rarely, sandstone is predominant. The features of this facies assemblage are consistent with deposition in braided channels, probably at the toes of fan-deltas (e.g., Ethridge and Wescott, 1984; Nemec and Steel, 1984) proximal to the bounding fault scarps. The presence of minor carbonaceous shale layers interbedded with coarse conglomerate indicate intermittent swampy conditions or subsidence followed by trangression of lacustrine conditions over the fan delta. The red shale, siltstone, sandstone, and conglomerate unit within the upper member may represent an alluvial plain within the fan delta.

\section{TECTONIC IMPLICATIONS}

The Emsian to Eifelian lower member of the McAdams Lake Formation was deposited along the boundary between the Bras d'Or and Mira terranes (Fig. 1). The abundance of Bras d'Or terrane clasts in conglomerate throughout the McAdams Lake Formation indicates that the Bras d'Or terrane had strong topographic relief and that the Georges River Fault remained active throughout the deposition of the formation. In contrast, clasts derived from the Coxheath Hills belt were observed only in the lower member of the formation, where they are a minor component. The lack of abundant clasts from the Coxheath Hills belt indicates that it was not a strong topographic feature at this time. However, the presence of detritus from both the Mira and Bras d'Or terranes in the lower member of the McAdams Lake Formation indicates that these two terranes were assembled by the Early Devonian, and the upward increase in abundance of Bras d'Or terrane clasts suggests that the formation was deposited on a subsiding Mira terrane basement. The change from lacustrine/fluvial to fluvial/alluvial sedimentation recorded by the lower and upper members, respectively, of the McAdams Lake Formation suggests an increase in tectonic activity along the Bras d'Or-Mira terrane boundary (the Georges 
River Fault) which resulted in an increased rate of uplift in the Bras d'Or terrane and consequent progradation of the fan delta to fill the basin.

The original shape and extent of the basin in which the McAdams Lake Formation was deposited is unknown because only a portion of the orginal basin is now exposed. Data from sparce paleocurrent indicators suggest a basinal paleoslope which dipped toward the northeast during deposition of the lower member. During deposition of the upper member the rate of subsidence increased and several reversals in the sediment dispersal patterns from northeast to southwest occurred as progradation of the fan proceeded. It is unclear if these data represent major regional tectonic influences or local variations in deposition conditions. The rounded nature of clasts indicates significant transport distances, and clast compositions indicate that the main source area was the Boisdale Hills belt, now located northwest of the formation. The present basin asymmetry suggests deposition in a distensive (half-graben) style setting (e.g., Hamblin, 1989; Hamblin and Rust, 1989), subsequently modified by movements on basin-bounding faults.

A significant hiatus occurred between deposition of the McAdams Lake Formation and the unconformably overlying Grantmire Formation, during which time the McAdams Lake Formation was deformed into a northwest-dipping folded antiform, and movement along the Gillis Lake Fault was probably initiated. The northeast-trending axial traces of minor folds are parallel (not oblique) to the orientation of the Georges River and Gillis Lake faults, suggesting that basin evolution during this time changed from extensional to compressional and that strike-slip motion was not a contributing factor.

The thick, red, coarse conglomerates of the Grantmire Formation are interpreted to represent deposition on marginal alluvial fans (Gibling et al., 1987). This suggests that after compressional deformation of the McAdams Lake Formation, the overlying Grantmire Formation was deposited in a Lower Carboniferous extensional setting. The regional significance of the Late Devonian compressional deformation recorded in the McAdams Lake Formation is uncertain, as it apparently post-dated the Acadian orogeny but pre-dated Carbonferous (Alleghenian) deformation. Its occurrence may have implications for tectonic models which suggest an extensional regime during the Late Devonian (e.g., Lynch, 1996; Murphy and Keppie, 1998).

The McAdams Lake Formation probably extends to the northeast under the Sydney Basin. It is expected that it could be recognized by a distinct seismic signature, as a result of its deformed character compared to overlying units.

\section{REgIONAL CORRELATIONS}

The McAdams Lake Formation is one of the oldest units in the Maritimes Basin (Williams, 1973) of Cape Breton Island (Fig. 6). The Maritimes Basin began to form in the Middle Devonian, and strata in the basin constitute an overlap sequence linking all of the tectonostratigraphic basement terranes in the northern Appalachian orogen (Fig. 1).

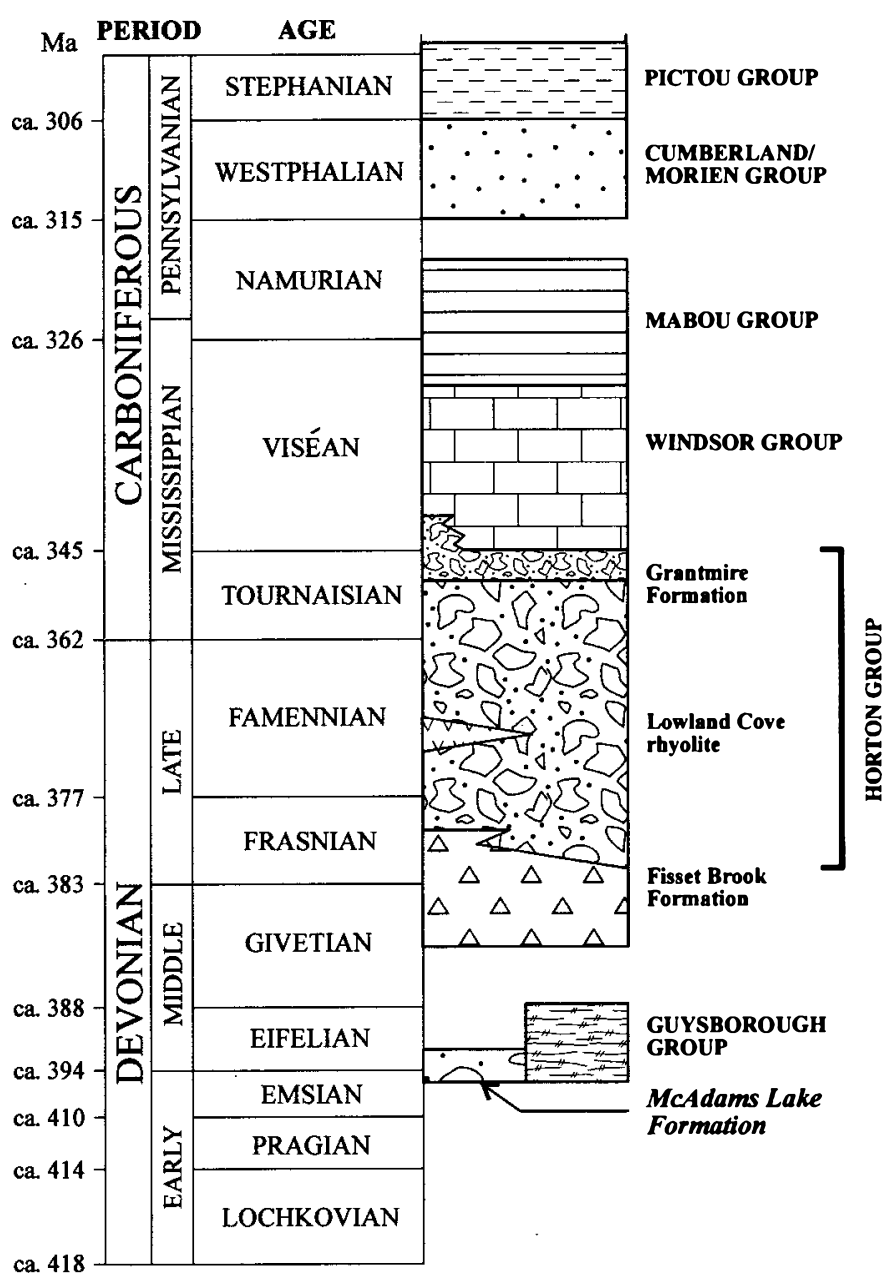

Fig. 6. Stratigraphic position of the McAdams Lake Formation compared to other post-Acadian units in the Maritimes Basin of Cape Breton Island. Time scale is from Tucker et al. (1998) and Okulitch (1995).

The only unit of similar age to the McAdams Lake Formation in Cape Breton Island is the Guysborough Group of the Isle Madame area (Fig. 1). The Guysborough Group extends into northern mainland Nova Scotia (Cormier, 1994; Cormier et al., 1995; White and Barr, 1998b). Although fossils have not been found, the Guysborough Group includes volcanic rocks dated at ca. 389 to $385 \mathrm{Ma}$ (U-Pb zircon ages in Cormier et al., 1995 and Dunning et al., 1997), and hence this unit is similar in age to the McAdams Lake Formation (Fig. 6), using the time scale of Tucker et al. (1998). The Murphy Brook Formation of northern mainland Nova Scotia (Fig. 1 inset) contains fossil plants (Taeniocrada and Psilophyton; Forbes et al., 1979) that were assigned a late Emsian to early Eifelian age (A. Kasper in Donohoe and Wallace, 1985), identical to the age of the McAdams Lake Formation.

With the exception of the McAdams Lake and Murphy Brook formations and the Guysborough Group (Fig. 1 inset), the earliest post-orogenic deposits in the Maritimes Basin are interbedded volcanic and sedimentary rocks of the Fisset Brook Formation (Figs. 1, 6). Rhyolite in the Fisset Brook Formation in western Cape Breton Island has yielded U-Pb 
zircon ages of ca. $374 \mathrm{Ma}$ (Barr et al., 1995; Dunning et al., 1997), and rhyolite in the Lowland Cove area of northern Cape Breton Island (Figs. 1, 6) has been dated at ca. $360 \mathrm{Ma}$ (G. Dunning, 1997, unpublished data). These ages indicate that the Fisset Brook Formation is significantly younger than the McAdams Lake Formation, and that the unconformity between the McAdams Lake Formation and the Grantmire Formation marks a hiatus of ca. $40 \mathrm{Ma}$ (Fig. 6). However, this hiatus may be partly filled by lower units of the Horton Group, which may extend into the Late or even Middle Devonian in some areas (Fig. 6).

\section{ECONOMIC POTENTIAL}

The lower member of the McAdams Lake Formation has been periodically explored as a possible source rock for hydrocarbons. Fletcher (1878) reported the presence of coal in shales near McAdams Lake, and subsequently these units were prospected for potential oil resources (Smith and Naylor, 1990 , and references therein). Oil shale was reported to outcrop in a brook near the west shore of McAdams Lake (Fig. 2), where it was first mined about 1890 (Gilpin, 1899). Oil shale samples from the mine were reported by Gilpin (1899) to burn freely and give oil yields of 15 to 20 gal./ton (75-100 $1 t / t$ ). Analyses of shale samples in the lower member from outcrops along Bourinot Boad and in the McAdams Lake drill core shows them to be thermally mature (within the oil window), to contain 2.6 to $18.6 \%$ organic carbon, and to produce hydrocarbon yields of 1 to $20 \mathrm{lt} / \mathrm{t}$ (Avery and Hacquebard, 1977; Pounder, 1979; Smith and Naylor, 1990). However, Smith and Naylor (1990) concluded that the shale offers little or no potential as an oil shale resource due to its low oil yield, and that the organic component of the shale is derived from carbonaceous (humic), rather than algal, remains. However, the organic-rich shales of the upper member have not been explored for hydrocarbon potential.

Anthracite coal was reported by Potter (1977) in the two holes drilled by the Nova Scotia Department of Mines in 1976 near McAdams Lake (Fig. 2). However, Smith and Naylor (1990) reported that the anthracite coal is better described as carbonaceous or coaly shale $(0.86-1.06 \%$ mean Ro, high volatile A bituminous; Avery and Hacquebard, 1977).

Gossan zones are locally developed in conglomeratic units where pyrite-rich layers and veins are common and trace amounts of copper mineralization have been reported from drill core in the Gillis Lake area (Oldale, 1967).

\section{Conclusions}

The latest Emsian to Early Eifelian McAdams Lake Formation is one of the oldest units deposited in the Maritimes Basin. It was deposited in a small half-graben on the Mira terrane with most of the sediments derived from the by-then adjacent Bras d'Or terrane. The lower sandstone, siltstone, shale, and conglomerate member was deposited in a lacustrine environment, with episodic, rapid deposition of conglomeratic debris flows in a fan delta setting. The grey conglomerate and sandstone of the conformably overlying up- per member is interpreted to have been deposited in a fandelta environment. A hiatus of ca. 40 Ma separated deposition of the McAdams Lake Formation from deposition of the unconformably overlying Grantmire Formation, during which time compression resulted in the deformation of the McAdams Lake Formation into a folded antiformal structure.

The McAdams Lake Formation and equivalent units in Atlantic Canada may not be as localized as previously thought but instead may represent an earlier Horton-like basin system with similar facies and economic possibilities that have yet to be explored.

\section{ACKNOWLedgements}

Funding for the field work related to this project was provided by Natural Sciences and Engineering Research Council research grants to S.M. Barr. We thank R. Naylor and J. Calder for helpful discussions, and R. Naylor for helpful comments on an earlier version of the paper. We thank the journal reviewers, M.R. Gibling and A.P. Hamblin, and editor G.L. Williams, for their perceptive comments and recommendations which led to substantial improvements in the manuscipt.

Alcock, F.J. 1947. Geology and Economic Minerals of Canada, Third Edition. Geological Survey of Canada, Economic Series, 1, Chapter 3, pp. 98-155.

AverY, M. and HacquzBard, P. 1977. Vitrinite reflectance measurements on Devonian coals cored in two holes at McAdam Lake. Atlantic Geoscience Centre, Geological Survey of Canada, Report No. EPGS-DOM 1-77MPA, 2 p.

Barr, S.M. and Macdonald, A.S. 1992. Devonian plutons on southeastern Cape Breton Island, Nova Scotia. Atlantic Geology, 28, pp. 101-113.

BARR, S.M. and RAEsIDE, R.P. 1989. Tectonostratigraphic terranes in Cape Breton Island, Nova Scotia. Implications for the configuration of the northern Appalachian Orogen. Geology, 17, pp. 822-825.

BARR, S.M. and SETTRR, J.R.D. 1986. Petrology of granitoid rocks of the Boisdale Hills, central Cape Breton Island, Nova Scotia. Nova Scotia Department of Mines and Energy, Paper 84-1, $75 \mathrm{p}$.

Barr, S.M., Dunning, G.R., Raeside, R.P., and Jamieson, R.A. 1990. Contrasting U-Pb ages from plutons in the Bras d'Or and Mira terranes of Cape Breton Island, Nova Scotia. Canadian Journal of Earth Sciences, 27, pp. 1200-1208.

Barr, S.M., White, C.E., and Macdonald, A.S. 1992. Revision of upper Precambrian - Cambrian stratigraphy, southeastern Cape Breton Island, Nova Scotia. In Current Research, Part D. Geological Survey of Canada, Paper 92-1D, pp. 2126.

Barr, S.M., Macdonald, A.S, Arnott, A.M., and Dunning, G.R. 1995. Field relations, structure, and geochemistry of the Fisset Brook Formation in the Lake Ainslie - Gillanders Mountain area, central Cape Breton Island, Nova Scotia. Atlantic Geology, 31 pp. 127-139.

BarR, S.M., WhItr, C.E., and Macdonald, A.S. 1996. Stratigraphic, tectonic setting, and geological history of late Precambrian volcanic-sedimentary-plutonic belts in southeastern Cape Breton Island, Nova Scotia. Geological Survey of Canada, Bulletin 468, 84 p. 
Bell, W.A. 1938. Fossil flora of Sydney coalfield, Nova Scotia. Geological Survey of Canada, Memoir 215, 334 p.

Bell, W.A. and Goranson, E.A. 1938. Sydney Sheet (West Half). Geological Survey of Canada, Department of Mines and Resources. Map 360A. Scale 1 inch to 1 mile.

Boehner, R.C. and GILes, P.S. 1986. Geological map of the Sydney Basin. Nova Scotia Department of Mines and Energy, Map 86-1, scale 1:50 000 .

Cormirr, C.F.M. 1994. Field relations, petrology, and age of volcanic and associated sedimentary and gabbroic rocks in the Guysborough area, Nova Scotia. M.Sc. thesis, Acadia University, Wolfville, Nova Scotia.

CormirR, C.F.M., BarR, S.M., and Dunning, G.R. 1995. Geological setting and petrochemistry of early Middle Devonian volcanic and gabbroic rocks in the Guysborough area, Nova Scotia. Atlantic Geology, 31, pp. 153-166.

Donomoz, H.V., JR. and Wallace, P.I. 1985. Repeated orogeny, faulting, and stratigraphy in the Cobequid Highlands, Avalon Terrane of northern Nova Scotia. Geological Association of Canada/Mineralogical Association of Canada, Field guide for Excursion 3, University of New Brunswick, 77 p.

Dorf, E. and CoOper, J.R. 1943. Early Devonian plants from Newfoundland. Journal of Paleontogy, 17, pp. 264-270.

Dunning, G., PiPer, D.J.W., Giles, P.S., Pe-PiPer, G., and Barr, S.M. 1997. Chronology of early phases of rifting of the DevonianCarboniferous Magdalen Basin in Nova Scotia from U-Pb dating of rhyolites. Abstract in Geological Association of Canada/Mineralogical Association of Canada Annual Meeting, Ottawa, May 19-21, 1997, 22, p. A42.

Ehlers, E.G. and Blatt, H. 1982. Petrology-igneous, sedimentary, and metamorphic. W.H. Freeman, San Francisco, California, $732 \mathrm{p}$.

Ethridge, F.G. and Westcotr, W.A. 1984. Tectonic setting, recognition and hydrocarbon potential of fan-delta deposits. In Sedimentology of Gravels and Conglomerates. Edited by E.H. Koster and R.J. Steel. Canadian Society of Petroleum Geologists, Memoir 10, pp. 217-235.

Fletcher, H. 1878. Report on the geology of parts of the counties of Victoria, Cape Breton, and Richmond, Nova Scotia. In Geological Survey of Canada, Report of Progress for 187677, pp. $402-456$.

Forbes, W.H., Kasper, A.E., Donohor, H.V., and Wallace, P. 1979. A new Devonian flora from Nova Scotia. In Mineral Resources Division, Report of Activities 1978. Edited by J.M. MacGillivray and K.A. McMillan. Nova Scotia Department of Mines and Energy, Report 79-1, p. 163.

Giblng, M.R. 1995. Upper Paleozoic rocks, Nova Scotia. In Chapter 5 of Geology of the Appalachian-Caledonian Orogen in Canada and Greenland. Edited by $\mathrm{H}$. Williams. Geological Survey of Canada, Geology of Canada, 6, pp. 493-523.

Gibling, M.R., Bozhner, R.C., and Rust, B.R. 1987. The Sydney Basin of Atlantic Canada: an upper Paleozoic strike-slip basin in a collisional setting. In Sedimentary Basins and BasinForming Mechanism. Edited by C. Beaumont and A.J. Tankard. Canadian Society of Petroleum Geologists, Memoir 12, pp. $269-285$.

Giles, P.S. 1983. Sydney Basin Project. Nova Scotia Department of Mines and Energy, Report 83-1, pp. 57-70.

GILPIN, E. 1899. New mineral discoveries in Nova Scotia. Transactions of the Nova Scotia Institute of Science, X, session 18981899, pp. 79-91.

Hamblin, A.P. 1989. Sedimentology, tectonic control, and resource potential of the Upper Devonian - Lower Carboniferous Horton Group, Cape Breton Island, Nova Scotia. Ph.D. thesis, University of Ottawa, Ottawa, Ontario.
Hamblin, A.P. and Rust, B.R. 1989. Tectono-sedimentary analysis of alternate-polarity half-graben basin-fill successions: Late Devonian-Early Carboniferous Horton Group, Cape Breton Island, Nova Scotia. Basin Research, 2, pp. 239-255.

Helmstaedt, H. and Tella, S. 1973. Pre-Carboniferous structural history of southeast Cape Breton Island, Nova Scotia. Maritime Sediments, 9, pp. 88-99.

Hutchinson, R.D. 1952. The stratigraphy and trilobite faunas of the Cambrian sedimentary rocks of Cape Breton Island, Nova Scotia. Geological Survey of Canada, Memoir 262, p. 124.

KEPPIE, J.D. 1979. Geological Map of the Province of Nova Scotia. Nova Scotia Department of Mines and Energy, scale 1:500 000.

LYNCH, J.V.G. 1996. Tectonic burial, thrust emplacement, and extensional exhumation of the Cabot Nappe in the Appalachian hinterland of Cape Breton Island, Canada. Tectonics, 15, pp. 94-105.

MacDougall, I., and Grimm, D.W. 1977. Drilling logs of Government Core Drill 1976. Province of Nova Scotia, Department of Mines Report 77-3, p. 16.

Mazerolle, G. and MacGillivary, G. 1975. Geology of the East Bay area, Cape Breton County, Nova Scotia. Nova Scotia Department of Mines, unpublished map, scale 1 inch to $1 / 4$ mile.

McGREGOR, D.C. 1966. Revision of report F1-4-1962-DCM to D.G. Kelley, on spores in sample from McAdam Lake, Nova Scotia (NTS-11K). Geological Survey of Canada, unpublished report Fl-3-1966-DCM, 1 p.

1977. Spores from the McAdam Lake Formation, in samples submitted by W. Potter (Nova Scotia Department of Mines) from two bores holes in Cape Breton Island(NTS-11K). Geological Survey of Canada, unpublished report Fl-12-1977-DCM, 2 p.

1995. Palynology of four samples of rock from the McAdam Lake Formation, Cape Breton Island, (NTS-11K/1), submitted for study by Sandra Barr (Acadia University). Geological Survey of Canada, unpublished report F1-3-1995-DCM, 2 p.

Miyashiro, A. 1974. Volcanic rock series in island-arcs and active continental margins. American Journal of Science, 274, pp. 321-355.

MURPHY, J.B. and KePPIE, J.D. 1998. Late Devonian palinspastic reconstruction of the Avalon-Meguma terrane boundary: implications for terrane accretion and basin development in the Appalachian orogen. Tectonophysics, 284, pp. 221-231.

Nemec, W. and Steer, R.J. 1984. Alluvial and coastal conglomerates: their significant features and some comments on gravelly mass-flow deposits. In Sedimentology of Gravels and Conglomerates. Edited by E.H. Koster and R.J. Steel. Canadian Society of Petroleum Geologists, Memoir 10, pp. 1-31.

Oldale, H. 1967. A report on diamond drilling completed in 1967 on tracts 66 and 67 map sheet $11 \mathrm{~K}-1-\mathrm{B}$, Coxheath Hills, Cape Breton, Nova Scotia. Nova Scotia Department of Mines, Assessment Report 13C-27(12).

Okulitch, A.V. 1995. Geological Time Scale, 1995. Geological Survey of Canada, Open File 3040.

Poole, W.H. 1967. Tectonic Evolution of Appalachian Region of Canada. In Collected Papers on Geology of the Atlantic Region. Edited by E.R.W. Neale and H. Williams. The Geological Association of Canada, Special Paper 4, pp. 9-51.

Potrer, W. 1977. Oil shale survey. In Minerals and Resources Division, Report of Activities 1976. Edited by D.A. Murray. Nova Scotia Department of Mines, Report 77-1, pp. 23-26.

Pounder, D. 1979. Carbonate sample descriptions, geochemical and palynological summary, Chevron Canada Resources Limited; 
Nova Scotia field work - 1979. Nova Scotia Department of Mines and Energy, Central Registry, File No. SC10798400.

RAEside, R.P. 1989. Geology of the metamorphic rocks of the Boisdale Hills, Cape Breton Island. In Mines and Energy Branch Report of Activities 1989, part A. Edited by D.R. MacDonald and K.A. Mills. Nova Scotia Department of Mines and Energy, Report 89-3, pp. 145-148.

SMITH, W.D. and NAYLOR, R.D. 1990. Oil shale resources of Nova Scotia. Nova Scotia Department of Mines and Energy, Economic Geology series 90-3, 73 p.

Streckeisen, A. and Le Maitre, R.W. 1979. A chemical approximation to the modal QAPF classification of igneous rocks. Neues Jahrbuch fur Mineralogie, 136, pp. 169-206.

Tucker, R.D., Bradley, D.C., Ver Straeten, C.A., Harris, A.G., EberT, J.R., and McCutcheon, S.R. 1998. New U-Pb zircon ages and the duration and division of Devonian time. Earth and Planetary Science Letters, 158, pp. 175-186.

Weeks, F.J. 1954. Southeast Cape Breton Island, Nova Scotia. Geological Survey of Canada, Memoir 277, 112 p.

1955. Grand Narrows map sheet. Canada Department of Mines and Technical Surveys, Map 1040A, scale 1:63 360.

1958. Mira map sheet. Canada Department of Mines and Technical Surveys, Map 1056A, scale 1:63 360.

Whalen, J.B., Currie, K.L., and Chappell, B.W. 1987. A-type granites: geochemical characteristics, discrimination, and petrogenesis. Contributions to Mineralogy and Petrology, 95, pp. 407-419.

WhIT, C.E. and BARR, S.M. 1998a. Geological map of the McAdams Lake Formation, Cape Breton Island. Nova Scotia Department of Natural Resources, Mineral and Energy Branch, Open File Map ME1998-14, scale 1:20 000.

1998b. Preliminary geological map of the Guysborough, Richmond, and Antigonish counties, Nova Scotia (parts of NTS sheets 11E/08, 11F/05, 06, 10, 11, 12, and 15). Nova Scotia Department of Natural Resources, Minerals and Energy Branch, Open File Map 1998-001, scale 1:100 000.

White, C.E., BARr, S.M., Bevier, M.L., and Kamo, S. 1994. A revised interpretation of Cambrian and Ordovician rocks in the Bourinot belt of central Cape Breton Island, Nova Scotia. Atlantic Geology, 30, pp. 123-142.

Williams, E.P. 1973. The Quebec and Maritimes Basin. In The Future Petroleum Provinces of Canada. Edited by R.G. McCrossan. Canadian Society of Petroleum Geology, Memoir 1, pp. 561588.

Williams, G.L., Fyffe, L.R., Wardle, R.J., Colman-Sadd, S.P., and Boehner, R.C. 1985. Lexicon of Canadian Stratigraphy, Volume VI, Atlantic Region.

Winchester, J.A. and FloYd, P.A. 1977. Geochemical discrimination of different magma series and their differentiation products using immobile elements. Chemical Geology, 20, pp. 325-343. 